\title{
Big Data as Object of International Legal Protection
}

\author{
Valentina P. Talimonchik* \\ Saint Petersburg State University \\ 7/9 University Embankment, St. Petersburg, 199034, Russia
}

Received 25.11.2018, received in revised form 14.02.2019, accepted 06.03.2019

Background/Objectives. The aim of the study is to identify the prospects for the international legal protection of Big Data at the universal and regional levels and to make an analysis of the legal means of protecting Big Data while regulating relations in the global information society.

Methods. A complex of general scientific and philosophical methods, including the logical, comparative-legal, formal-legal, systemic-structural, problematic-theoretical methods, as well as methods of analysis and synthesis, generalisation and description, were used in the research.

Findings. The study revealed that the existing international treaties in the field of intellectual property protection do not take into account the peculiarities of the complex objects protection. Under the complex objects of intellectual property, Big Data is meant. There is an objective need to establish a legal regime of information and communication systems as complex objects at a universal level. This can be done by adding a separate act to the Berne Convention for the Protection of Literary and Artistic Works of 1886.

Application/Improvements. The findings can be used in activities of international organisations to enhance their unification and harmonisation of the international information law.

Keywords: information and communication systems, international legal protection, Big Data, databases.

Research area: law.

Citation: Talimonchik, V.P. (2019). Big data as object of international legal protection. J. Sib. Fed. Univ. Humanit. soc. sci., 12(3), 455-469. DOI: 10.17516/1997-1370-0404.

\section{Introduction}

Conservatism is typical for the development of the legal protection of intellectual property at the universal level. With the advent of new technologies, existing international treaties have been revised and adapted to the requirements of new technologies to a lesser extent. Until the middle of the $20^{\text {th }}$ century the impact of

(C) Siberian Federal University. All rights reserved

* Corresponding author E-mail address: talim2008@yandex.ru

This work is licensed under a Creative Commons Attribution-NonCommercial 4.0 International License (CC BY-NC 4.0). 
scientific and technological progress on the development of copyright and patent law was insignificant. In particular, with the advent of radio and television, the system of allied rights has changed dramatically.

Scientific and technological progress in the $20^{\text {th }}$ century led to radical changes in the modern world. The very system of social relations changed. The development of information and communication technologies (ICT) had an impact on all spheres of society - economics, politics, social sphere and culture.

Today, the theory of the information society is stated in a number of international documents. Such documents include the Okinawa Charter on Global Information Society of July 22, 2000; the Declaration of Principles "Building the Information Society: A Global Challenge in the New Millennium"; as well as the Action Plan of the World Summit on the Information Society of December 12, 2003; Directive (EU) 2015/1535 of the European Parliament and of the Council of 9 September 2015 laying down a procedure for the provision of information in the field of technical regulations and of rules on Information Society services, Decision of the Council of Heads of Government of the CIS "On the strategy of cooperation of the CIS member states to build and develop the information society for the period up to 2025 and the Action Plan for its implementation", dated October 28, 2016.

It is not accidental that the problems of intellectual property protection are examined in fundamental studies on the law of information technologies by D.I. Bainbridge (Bainbridge, 2008), D. Campbell (Campbell, 2005), D. Rowland and E. Macdonald (Rowland \& Macdonald, 2005), I.J. Lloyd (Lloyd, 2008), A. Murray (Murray, 2010).

"Big Data" term refers to the statistical direction of programming. However, this direction does not imply the legal protection of the technology for collecting, processing and storing Big Data, as it takes into account only the protection of Big Data as such, the protection of the content of Big Data.

Since 2015 the Russian researchers in law have been interested in the problems of legal regulation of Big Data. A number of studies address the issue of privacy protection in the era of Big Data (Savelyev, 2015; Savelyev, 2018). The legal problems of using Big data are scrutinised (Chzan, 2018; Bulgakova, 2017). The issue of Big Data and competition laws were also reviewed in the research (Yutchison, 2017).

In the foreign legal doctrine there are already more than a hundred of publications on the problems of using Big Data, though the contribution of specialists in the field of international law to the problems under consideration is not so remarkable. More specifically, the foreign researchers looked into the impact of Big Data on human rights 
(Galit, 2017), as well as the connection of Big Data with the progressive development of international law (Fuller, 2014).

However, currently there are no monographic studies on the international legal protection of Big Data.

\section{Theoretical framework}

There is no consensus among researchers about the moment when the theory of the information society appeared. A. Matterlart points to earlier origins of the theory of the information society (Matterlart, 2003, p. 6). He dates the study of the theories of the information society back to Leibniz (1646-1716), who for the first time introduced an order relation as regards sets of numbers and put them in a strict hierarchy. Without denying the achievements of thinkers of the $7^{\text {th }}-19^{\text {th }}$ centuries, I shall note that the first studies of the information society appeared only in the 1960s (Y. Hayashi, F. Machlup and T. Umesao).

Since the goal of the present work is to identify the peculiarities of the legal regulation of issues of the information society, for a full description of the information society it is important to determine the characteristics of social relations in the information society.

It seems that modern relations concerning the creation, dissemination, obtaining of information, and other actions on its circulation, storage and destruction demonstrate a wide range of subjects. One should agree with J. Masuda, who argues that "the most developed stage of the information society should be the society of mass production of knowledge, in which computerisation allows each individual to create knowledge and use it for self-realisation" (Masuda, 1983, p. 33). More and more individuals and associations of individuals - legal entities, public associations, etc., become the subjects of informational relations. This is due to the fact that ICTs allow direct communication between people regardless of state borders. Thus, powerless entities get the opportunity to participate in informational relations, which does not eliminate the participation of empowered subjects in them.

The object of informational relations has been also changing. Until the middle of the $20^{\text {th }}$ century there were separate, isolated carriers of information, but after that opportunities for knowledge dissemination have expanded. Subjects of information relations have acquired the ability to operate information systems, including, above all, the Internet. Thus, in the information society these relations predominantly cover the functioning of information systems.

As it seems, at the present stage of development, relations in the information society are a part of the structure of civil society. 
The ideas of civil society in Russia began to develop in the late $19^{\text {th }}-$ early $20^{\text {th }}$ centuries. Without getting into the discussion on the concept of civil society, one can be content with the definition of civil society given by S.V. Chernichenko: "Civil society is an area of social relations in which members of society as a whole interact with each other individually or collectively - through the organisations that they create, and in which the state role is limited to one of the guarantor of such interests, without government interfering with the relations between individuals as long as they do not affect the public interests, that is, the interests of the society as a whole, being managed by the state" (Chernichenko, 2009, p. 539).

Today, the information society is formed in the private sphere via the interaction of non-state actors. The information society is an integral part of civil society, including relations associated with the application of ICT.

\section{Statement of the problem}

In the information society, the protection of intellectual property is a key factor for its development.

The Okinawa Charter on Global Information Society established that the protection of intellectual property rights to information technology is critical for promoting ITrelated innovations, fostering competition and widespread adoption of new technologies. The Charter welcomed the joint work of representatives of the authorities on the protection of intellectual property and instructed the experts to discuss further issues of work in this area. It should be noted that the Charter provided for the protection of intellectual property in the field of information technology, which is an object not covered by the Berne Convention for the Protection of Literary and Artistic Works of 1886 and the Paris Convention for the Protection of Industrial Property of 1883.

Nowadays, the development of relations in the global information society faces the problem of insufficient legal protection of scientific and technical achievements.

One of these scientific and technological advances is Big Data. During this study it is necessary to answer the questions like what kind of legal protection should be given to Big Data at the universal level, what is Big Data as an object of international legal regulation?

\section{Methods}

The aim of this study is to identify the prospects for the international legal protection of information and communication systems, in particular, Big Data, at the universal and 
regional levels, and to analyse the existing legal means of protecting Big Data. For this, this, first of all, the analysis of the existing database protection systems shall be made at the universal, regional and national levels, a description and a generalisation of the analysis results. For the analysis of the existing database protection systems, formallogical and problem-theoretical research methods have been used. At the same time, the comparative jurisprudence method is used to analyse existing database protection systems at the national level in order to discern similar features and differences in the respective systems and to outline the prospects for adopting experience of particular states at the universal level.

\section{Concept headings}

The closest to the Big Data object, the protection of which is prescribed at the universal level, is databases.

The need of the legal means of protection to comply with the features of protected objects became more visible when the Directive of the European Parliament and the Council No. 96/9/EC on the legal protection of databases was adopted on March 11, 1996. This Directive provided for sui generis rights. The condition for the emergence of this right is the "substantial investment" that is required to create the objects of the new law. The sui generis right to databases is protected for 15 years and implicates the exclusive control of the database creator over the retrieval and reuse of its contents.

In legal doctrine, the emergence of sui generis right is coupled with the problem of the legal protection of non-original works. T.K. Jehoram writes that "copyright is not an appropriate means to protect databases. Therefore, the Database Directive contains sui generis protection for those databases that are not original" (Jehoram, 1998, p. 108).

The tendency to bolster the methods of legal protection of computer technologies, existing at the regional level, is currently absent at the universal level. Not taking into account the EU experience, the WIPO Copyright Treaty of December 20, 1996, stipulates that computer programmes and databases are protected by copyright. Besides, Article 1 of this Treaty specifies that the treaty is a special agreement in the sense of Article 20 of the Berne Convention for the Protection of Literary and Artistic Works. Article 4 of the Treaty states that computer programmes are protected as literary works in the sense of Article 2 of the Berne Convention. This protection applies to computer programmes regardless of the way or form of their expression. Article 5 of the Treaty provides for that databases are protected if they contain essentials of intellectual creativity. The databases are protected as such, as the given protection is not able to presume that the 
data and materials in the database are significant to copyright. Provisions on the legal protection of computer programmes and databases are contained in Articles 1 - 7 of the Treaty. Issues of legal protection are settled in the Treaty in the most general form, therefore the content of the Treaty seems to be incomplete to regulate the protection of software and databases at the universal level.

At the same time, the national legislation (for example, in France, Switzerland, Germany) provides for protection of databases under copyright law.

As the copyright protection of computer programmes and databases is stated in the legislation of a number of states, albeit in an insufficiently specific form, a number of problems related to the implementation of the relevant legal norms have arisen. There is no doubt that the concepts of "publication", "copying" as applied to computer programmes and databases have some certain features that distinguish them from traditional copyright objects. When there are no definitions of the corresponding notions in the legislation, their meaning can be revealed only by examining the established practice of judicial and administrative bodies of individual states.

In connection with the difficulties of law enforcement, the practice of the United States Copyright Office is of considerable interest. The analysis of its precedents was given by its employee Harriet Lee Oler (Oler, 1998).

The Copyright Office registered the databases as "books" in class A, but during the registration they made less stringent requirements for originality. Under the publication the Copyright Office understood the reproduction of the programme in a form that is perceived or accessible to human eyes. The date of the sale of the programme or its offer for sale to consumers was traditionally taken as the date of the first publication. As for copying, copies of the programme may be in digital forms, on diskettes, in interfaces. The main criterion for copying is to create copies in a language that is accessible to human comprehension.

At this time, it should be in mind that the intended purpose of programmes and databases changed in the 1980-1990s. Computer programmes and databases are becoming increasingly important not only as separate technical phenomena, but also as the most vital components of a qualitatively new technical phenomenon - computer networks. Consequently, legal regulations on the protection of programmes and databases contained in the legislation of different states should be specific and similar, if possible.

The fact that Big Data should be granted copyright protection is questionable, given the practice of national courts to recognise the patentability of artificial intelligence, summarised by Mizuki Hashiguchi (Hashiguchi, 2017). 
In the USA, an example of acknowledging the patentability of the method of automatic animation of lip and facial expression synchronisation in computer graphics for character creation is the case McRO.Inc. v. Bandai Namco Games America Inc. The federal court considered that this method is patentable, since it does not lead to an abstract idea. The court took into consideration the specifics of the automatic method, covering individual operations with distinctive characteristics. The method, which includes individual operations, is intended to translate information into a specific format used to create characters. Moreover, the court reckoned in features of the industrial applicability of this invention. First, it is not just the methodology that is applied. Secondly, the invention cannot be used without the use of computer technology. Finally, the court concluded that the processes that automate the tasks performed by people are patentable.

In the case of $L L C \mathrm{v}$. Microsoft Corporation the invention of self-forming databases has been recognised as patentable. Usually computer programmes determine the structure of the database. For the LLC database, the programme was not needed, as the database configured itself on its own. The District Court for the Central District of California decided that the object was not patentable and was an abstract idea. Nevertheless, the Federal Court drew attention to the fact that the invention improves the capabilities of the computer in a certain way and is a special technical solution to the problem in the field of software. The significant contribution of the invention to the development of computer technology was recognised.

In general, the US courts are guided primarily by the criterion of the utility of the invention which has elements of artificial intelligence. The last example shows that artificial intelligence and Big Data are technologically interrelated.

Obviously, Big Data cannot be likened to a "simple" database. It is not difficult to see that Big Data is more complex in its structure. It is an information and communication system capable of collecting and processing information, providing access to it, including the means of artificial intelligence.

If we turn to Article 2 of the Berne Convention, it can be concluded that the Berne Convention does not make allowance for complex objects of copyright. These cannot include books, brochures and other written works; lectures, addresses, sermons and other similar works; drawings, paintings, architecture, sculpture, engraving and lithography works; photographic works and the works created in a manner similar to photography; works of applied art; illustrations, maps, plans, sketches and plastic works related to geography, topography, architecture or science. Dramatic and musical- 
dramatic works, choreographic works and pantomimes are components of a more complex object - theatrical performance. In fact, the only complex object settled by the Berne Convention is cinematographic works, to which the works created in a manner analogous to cinematography (mainly using harmonisation provisions) are equated.

As a consequence, it is becoming necessary to establish the legal regime of complex objects in a separate act to the Bern Convention. This applies not only to Big Data, but also to other results of the infocommunication revolution, namely the site, computer models, television format and audio-visual format, and, finally, artificial intelligence.

The significance of the Big Data problem is realised by WIPO. The statement of the Director General of WIPO at the session of the General Assembly of the Member States of WIPO (October 2-11, 2017) contains the following provision, "and finally, the last area I want to talk about and in which, in my opinion, the Organisation should start working albeit rather slowly in the first stage, is a rapidly developing "sector of Big Data", "Internet of things" and artificial intelligence. This area has a tremendous impact and diverse dimensions, many of which go far beyond the bounds of intellectual property, and therefore it is necessary to ensure that we do not deviate from the Organisation's mandate in this way. Thus, we could focus on a more active use of artificial intelligence and Big Data in the context of IP administration. We have developed several applications for the purposes of translating, classifying and searching for images; a number of IP offices, which create their software products, follow the same path. It is necessary to create mechanisms to exchange information about the work carried out by each entity and to use the results of each other's work to avoid duplication of efforts in order to make IP administration meet the requirements of technical progress. There is a flip side to the coin though: it is about the influence of the classical IP system on "Big Data" and artificial intelligence. In particular, it is necessary to understand how the IP system functions in this area from the point of view of solving its main task that is the promotion and dissemination of innovation. This raises a lot of questions, but our knowledge base in this area is just beginning to form. It seems useful to develop a common understanding of these issues by increasing the number of international events that allow sharing information about changes and practical methods of work." As we can see, WIPO is only approaching the understanding of new phenomena; no measures are being taken to regulate them.

The efforts of WIPO alone cannot solve the problem. Being a complex object, Big Data also requires other legal protection regimes: the protection of the privacy of legal 
entities and individuals, the protection of commercial, medical and other protected secrets.

More than 200 international documents contain a reference to a trade secret. For example, Article 27 of the Customs Code of the Eurasian Economic Union of 2017 establishes that information from preliminary decisions on the classification of goods, with the exception of information constituting state, trade, banking and other secrets protected by law, or other confidential information relating to the person concerned, is posted on the official Union website on the Internet. Article 38 of this document contains a rule that during the consultation process, the customs authority and the declarant may exchange information available to them, subject to compliance with the laws of the Member States on trade secrets. A trade secret may be the subject of interstate information exchange between customs authorities. When conducting a customs check, customs officials have the right to request and receive the documents and information necessary for the customs check from the state bodies of the Member States, including those constituting trade, banking, tax and other secrets protected by law in accordance with the legislation of the Member States. The state authorities of the Member States, at the request of the customs authority, provide the documents and information they have regarding the registration of organisations and individual entrepreneurs, the payment and calculation of taxes, data and (or) accounting documents and other documents and information necessary for customs checks, including those constituting trade, banking, tax and other secrets protected by law, in compliance with the requirements of the legislation of the Member States on the protection of state, commercial, banking, tax and other secrets protected by law. Professionals and experts drawn from other state bodies of the Member States should not disclose information constituting state, trade, tax, banking and other secrets protected by law, as well as confidential information relating to participants in foreign economic and other activities in the field of customs. The same duty is imposed on the customs authorities, their officials, customs representatives, customs carriers.

The issues of trade secrets are settled by bilateral international treaties on scientific, technical and innovative cooperation, on cooperation in the field of research and use of outer space for peaceful purposes, on cooperation and mutual administrative assistance in customs matters, on mutual protection of intellectual property rights used and received in the course of bilateral military-technical cooperation.

At the universal level, trade secrets are protected by TRIPS. The protection of confidential information is provided within the framework of protection against unfair 
competition. Part 1 of Article 39 of TRIPS contains a harmonisation clause according to which, in the process of ensuring effective protection against unfair competition, as provided for in Article 10-bis of the Paris Convention (1967), the Member States protect classified information in accordance with Paragraph 2 and information submitted to governments or government authorities in accordance with Paragraph 3. It is also directly established for the states to keep secret information obtained by them in authorising the sale of pharmaceutical or agrochemical products that use new chemicals.

It should be noted that Part 2 of this article of TRIPS allows the owners of classified information to determine its legal regime. Individuals and legal entities are given the opportunity to prevent information that is legally under their control being disclosed, obtained or used by other persons without their consent, in a manner contrary to honest commercial practice, provided that such information:

- is secret in the sense that it is generally or in a certain configuration and the selection of its components is not well known and easily accessible to persons in those circles who usually deal with such information;

- has commercial value because of its secrecy; and

- is subject to appropriate measures in these circumstances, aimed at preserving its secrecy, on the part of the person legally controlling this information.

However, non-disclosure agreements cannot fully protect commercial secrets from third parties. The technology of industrial espionage is very diverse: from bribing employees to using special software for hacking information systems. Legal entities, as a rule, connect their information systems with the Internet; specialised information systems (for example, Payrus) are placed on the Internet. Article 39 of TRIPS is little adapted to tort relations in the field of information.

A number of foreign countries know the practice of special conflict-of-law in defamation and privacy. Special conflict-of-law rules regarding defamation and privacy exist in the UK, the USA, Switzerland, Japan, China, and Turkey. Special conflict-of-law of the issues of trade and other secrets could not be found. Most often, the owner of the secret is interested in stopping the dissemination of information, prohibiting their use in the business of the offender, which is why special conflict-oflaw provisions is necessary.

\section{Discussion}

The issue of the implementation of privacy protection when using Big Data has already been considered in fundamental research on the law of information technology. 
Studying privacy issues, D. Rowland, U. Kohl and A. Charlesworth (Rowland, Kohl \& Charlesworth, 2017) turned to EU acts, considering the problems of exercising them when using the Big Data. However, this study did not address the problems of using regional experience at a universal level.

The same approach to the definition of personal data is characteristic of the OECD Guidelines for the Protection of Privacy and Cross-Border Flows of Personal Data of September 23, 1980, the Convention on the Protection of Individuals with regard to the automated processing of personal data of 1981. In these documents, personal data is defined as any information about a specific or identifiable individual. Thus, the protected data is any information about a private person that can be individualised. Such a wide range of protected information allows protecting personal data in the changing technologies used for data collection and processing. In particular, the range of protected data includes PIN codes, logins, passwords, etc.

The existing international documents relating to the protection of personal data as an integral part of privacy protection are ultimately aimed at harmonising the internal law of individual states. The issues of international cooperation in them have been resolved in a very limited manner, taking into account the traditional forms of cooperation of states.

Thus, the OECD Guidelines stipulate that OECD member states will establish procedures for information exchange regarding the Guidelines, as well as mutual assistance in procedural and investigation matters. This document does not provide more specific provisions.

The 1981 Convention contains clearer procedures for mutual assistance. The said Convention suggests that each party should establish one or more bodies to assist in the implementation of the provisions of the Convention; the party shall inform the Secretary General of the Council of Europe of the designated authorities; the designated authorities shall receive requests for assistance from the authorities of other states and fulfill these requests.

On November 8, 2001, in addition to the 1981 Convention, the Protocol that contains important provisions on the monitoring bodies created by each state party to the convention was signed. Each Party provides one (or more) supervisory body that is responsible for enforcing the restrictions of its national law, ensuring the implementation of the principles set out in Chapters II and III of the 1981 Convention and the Protocol.

The system of supervisory authorities, which has been formed since 2001, contributes both to interstate cooperation and the protection of the rights of the data 
subject. The possibility of individuals to contact supervisory authorities regarding the protection of their personal data creates the possibility of cross-border cooperation related to the protection of personal data. In fact, the system of supervisory authorities is the prototype of an international network for the protection of privacy. No less significant is the fact that the powers of the authorities also include those to investigate and participate in jurisdictional proceedings. Thus, the authorities are given powers to protect personal data.

The 1981 Convention provides for a special procedure that is assistance to data subjects permanently residing abroad. Under this procedure, any person may address to an authorized body in the territory of his/her place of residence in order to obtain information about personal data in another state. In the same way, you can submit a request for correction or cancellation of data.

Thus, the issues of mutual assistance, regulated by the 1981 Convention, take into account the interests of individuals, information about which may be in another state. Thus, the institution of legal assistance is being developed, allowing it to be provided by authorised bodies at the request of individuals in the framework of the administrative procedure. This experience requires borrowing at a universal level.

At the same time, the formation of the legal foundations of the global information society is largely spontaneous. Thus, there is no systematic vision of what the legal regulation corresponding to the level of development of scientific and technological progress should be within the framework of the institutional mechanism of state cooperation.

It should be noted that today the proposals for the conclusion of universal international treaties come mainly from non-state actors. The International Conference of Data Protection and Privacy Commissioners adopted a resolution on "Privacy and Personal Data Standards", by which it created a working group to draft a universal treaty and indicated criteria for the development of such a project. It is intended to submit the articles of the agreement to the UN. Thus, scientists, international forums offer concrete projects, despite the fact that there is no systematic work within the UN, WIPO, ITU and UNESCO.

\section{Conclusion}

Information and communication systems as complex objects of intellectual property need legal regulation at a universal level. Big data is an information and communication system capable of collecting and processing information, providing 
access to it, including using artificial intelligence. The task of legal protection of complex objects as such is proposed to be solved within the framework of WIPO by developing and adopting a separate act to the Berne Convention for the Protection of Literary and Artistic Works of 1886.

In order for international law to be a flexible privacy instrument adapted to the needs of each individual, it is necessary to introduce new privacy protection mechanisms through a combination of treaty and non-treaty mechanisms. The regulation of the processing of personal data at a universal level could be such a mechanism. To guarantee privacy at a universal level, it is possible to create networks following the example of regional consumer protection networks. The creation of such networks may base on an international treaty or a resolution of an international organisation. Networks can exchange information, assist in resolving disputes, and ensure the cooperation of judicial and administrative bodies.

\section{References}

Bainbridge, D.I. (2008). Introduction to Information Technology Law, 6th ed., Edinburg, Pearson Education Limited, 665 p.

Bulgakova, E.V. (2017). Metody analiza Big Data v reshenii iuridicheskih zadach [Methods of Big Data analysis in resolving legal tasks], In Pravo i Informatsiia: voprosy teorii i praktiki [Law and information: theory and practice], 90-96.

Campbell, D, Ban, C (Eds.). (2005). Legal Issues in the Global Information Society, New York, Oceana Publications Inc., 758 p.

Chernichenko, S.V. (2009). Ocherki po filisofii i mezhdunarodnomu pravu [Essays on philosophy and international law]. Moscow, Nauchnaia Kniga, 770 p.

Chzan, M. (2018). O vozmozhnostiyakh reagirovat' na vyzovy verkhovenstvu zakona pri primenenii Big Data [Concerning law domination opportunities to respond to challenges in the application of Big Data], In Informatsionnoe pravo [Information Law], 3, 30- 32.

Fuller, R. (2014). Structuring Big Data to Facilitate Democratic Participation in International, In International Journal of Legal Information, 42 (3), 504-516.

Hashiguchi, M. (2017). The Global Artificial Intelligence Revolution Challenges Patent Eligibility Laws, In Journal of Business \& Technology Law, 13 (1), 1-35.

Jehoram, T.C. (1998). Copyright in Non-Original Writings Past-Present-Future? In Intellectual Property and Information Law. Essays in honour of Herman Cohen Jehoram, Hague, 108. 
Kondratenko, A.B. (2017). Vozmozhnosti primeneniia Big Data v obrazovanii v epokhu tsifrovogo obshchestva [The possibilities to apply Big Data in education in the digital age], In Vestnik Kalinigradskogo filiala Sankt-Petersburgskogo universiteta MVD Rossii [Bulletin of the Kaliningrad branch of St. Petersburg University of the Ministry of Internal Affairs of Russia], 4, 112-115.

Lloyd, I.J. (2008). Information Technology Law, 5th ed., Oxford, Oxford University Press, $597 \mathrm{p}$.

Masuda, Y. (1980). The Information Society as Post-Industrial Society, Bethesda, World Future Society, $171 \mathrm{p}$.

Matterlart, A. (2003). The information society: an introduction, London, SAGE Publication Ltd, $182 \mathrm{p}$.

Murray, A. (2010). Information Technology Law: Law and Society, Oxford, Oxford university press, $596 \mathrm{p}$.

Oler, H.L. (1998). Statutory copyright protection for electronic digital computer programs: administrative considerations, In Law and computer technology, 7 (4), 96116.

Rowland, D., Macdonald, E. (2005). Information technologylaw, 3rd ed., Abingdon, Cavendish Publishing Ltd, 573 p.

Rowland, D., Kohl, U. \& Charlesworth A. (2017). Information Technology Law, 5th ed., London, Routledge, 549 p.

Galit, A. (2017). Can Big Data Revolutionize International Human Rights Law, In University of Pennsylvania Journal of International Law, 39 (1), 73-102.

Savelyev, A.I. (2015). Problemy primeneniia zakonodatel'stva o personal'nykh dannykh v epokhu Big Data [Problems of application of personal data legislation in the era of Big data], In Pravo [Law], 1, 43 - 66.

Savelyev, A.I. (2018). Napravleniia regulirovaniia Big Data i zashchita neprikosnovennosti chastnoi zhizni v novykh ekonomicheskikh realiiakh [Directions of Big data regulation and protection of privacy in the new economic reality], In Zakon [Statute], 5, $122-144$.

Yutchison, K. (2017). Big Data i zakonodatel'stvo o konkurentsii [Big data and competition legislation], In Pravo [Law], 1, 216 - 245. 


\section{Болышие данные как объект международно-правовой охраны}

В.П. Талимончик

Санкт-Петербургский государственный университет Россия, 199034, Санкт-Петербург,

Университетская набережная 7-9

$\overline{Ц е л ь ю ~ и с с л е д о в а н и я ~ с л у ж и т ~ в ы я в л е н и е ~ п е р с п е к т и в ~ м е ж д у н а р о д н о-п р а в о в о и ̆ ~ о х р а н ь и ~}$ Больших данных на универсальном и региональном уровнях, анализ правовых средств охраны Больших данных при регламентачии отношений в глобальном информачионном обществе. В результате исследования установлено, что существующие международные договоры в сфере охраны интеллектуальной собственности не учитывают особенностей охраны сложных объектов, к которым относятся Большие данные. Существует объективная потребность в установлении правового режима информаиионно-коммуникационных систем как сложных объектов на универсальном уровне. Это может быть сделано путем принятия отдельного акта к Бернской конвенции об охране литературных и художественных произведений 1886 г.

Ключевые слова: информационно-коммуникационные системы, международно-правовая охрана, Большие данные, базы данных.

Научная специиальность: 12.00.00 - юридические науки. 